\title{
IMPLEMENTASI LATIHAN OLAHRAGA RENANG ANAK AUTIS
}

\author{
Sabaruddin Yunis Bangun \\ Fakultas Ilmu Keolahragaan, Universitas Negeri Medan \\ email : unisbgn@unimed.ac.id
}

\begin{abstract}
The purpose of this study was to determine the implementation of exercise training in children with autism swimming pool Cemara Asri Medan, the increase and changes in motor and attitudes of children with autism demonstrate the importance of the research was conducted. This study uses descriptive qualitative approach, using the techniques of data collection: interviews, observation and documentation recording the conversation at the time of the study. The data analysis in this study by combining triangulation data from text interviews, field notes, photographs, vidio tape recorder and a notepad (memo). The results of the study are: a) Plan process conducted training has been going well, b) Preparation of training programs implemented already well under way, $c$ ) Implementation of the training has been going well executed, d) Evaluation Exercise conducted dudah goes well. The conclusion of this study is that the implementation of swimming exercise applied to children with autism already well underway.
\end{abstract}

Keywords: exercise, sports, pool, child, autism

\begin{abstract}
ABSTRAK
Penelitian ini bertujuan untuk mengetahui implementasi latihan olahraga renang anak autisme, terjadinya peningkatan dan perubahan motorik dan sikap anak autis membuktikan pentingnya penelitian ini dilakukan. Penelitian ini menggunakan metode deksriptif dengan pendekatan kualitatif, menggunakan teknik pengumpulan data: wawancara, observasi dan dokumentasi rekaman percakapan pada saat penelitian. Teknik analisa data dalam penelitian ini dengan triangulasi menggabungkan data-data dari naskah wawancara, catatan lapangan, foto, vidio tape recorder dan catatan kecil (memo). Hasil penelitian adalah: a) Rencana proses latihan yang dilakukan sudah berjalan dengan baik, b) Penyusunan progam latihan yang dilaksanakan sudah berjalan dengan baik, c) Pelaksanaan latihan yang dilaksanakan sudah berjalan dengan baik, d) Evaluasi Latihan yang dilaksanakan dudah berjalan dengan baik. Kesimpulan penelitian ini adalah bahwa implementasi latihan olahraga renang yang diterapkan terhadap anak autis sudah berjalan dengan baik.
\end{abstract}

Kata Kunci: latihan, olahraga, renang, anak, autisme 


\section{PENDAHULUAN}

Setiap manusia berhak mengembangkan diri melalui pemenuhan kebutuhan dasarnya. Dalam kaitannya adalah berhak mendapatkan kehidupan yang layak berikut pendidikan, jaminan kesehatan, ilmu pengetahuan, teknologi, seni, budaya dan mengembangkan bakat/kemampuannya agar dapat meningkatkan kualitas hidupnya.

Dalam kehidupan tidak ada manusia yang diciptakan sama dengan yang lainnya, dan diantara setiap manusia tersebut pastinya memiliki kekurangan. Tidak ada satu manusiapun yang ingin dilahirkan kedunia ini dengan menyandang kelainan atau memiliki kecacatan. Dengan demikian maka sejak kelahirannya ke dunia, anak cacat atau yang dikenal dengan anak berkebutuhan khusus (ABK) sudah tidak dikehendaki oleh kedua orang tuanya. Konsekuensi logis bila anak berkebutuhan khusus akan menghadapi banyak tantangan daru lingkungan keluarga, masyarakat maupun lingkungan pendidikan. Anak berkebutuhan khusus juga memiliki hak untuk tumbuh dan berkembang di tengah- tengah keluarga, masyarakat dan bangsa. Hak-hak yang dimaksud disini adalah hak-hak yang didapatkan oleh manusia pada umumnya, contohnya adalah berolahraga dengan menggunakan fasilitas dan prasarana olahraga sebagai jaminan kesehatan.

Salah satu jenis Anak berkebutuhan khusus adalah autisme, autisme adalah sebuah sindrom gangguan perkembangan sistem saraf pusat yang ditemukan pada sejumlah anak ketika masa kanak-kanak hingga masa-masa sesudahnya. Sindrom tersebut membuat anakanak yang menyandangnya tidak mampu menjalin hubungan sosial secara normal bahkan tidak mampu menjalin komunikasi dua arah.

Tidak ada data yang pasti sebenarnya jumlah penderita autis di Indonesia sampai saat ini, hanya saja penderita autisme diperkirakan 112.000 orang pada tahun 2013. Begitu juga dengan di Medan jumlah anak autis yang lahir di kota Medan khususnya bisa mencapai 250 orang pertahun (sumber media online). Melihat kenyataan ini sangatlah memprihatinkan bagi kita, sampai saat ini 
pemerintah belum maksimal mengatasi permasalahan ini yang terus bermunculan di tengah-tengah masyarakat. Walaupun uluran tangan orang-orang mampu terus hadir dan bertambahnya yayasan maupun lembaga masyarakat yang menangani anak-anak autisme.

Atas kenyataan ini, perlu kiranya dilakukan perbaikan dari hal yang kecil, sebagai peserta pendidik yang turut serta mendidik dan membina generasi muda bagi bangsa ini menjadi yang lebih baik lagi. Dari sisi pendidikan untuk mengembangkan anak-anak autis sangatlah memungkin yaitu melalui implementasi pelatihan olahraga renang anak autisme. Karena manfaat olahraga renang terhadap anak autis dapat menciptakan interaksi sosial yang baik terhadap anak-anak yang lain dan akan membuatnya lebih mampu beradaptasi dan menyesuaikan diri sehingga pada akhirnya dapat mengembangkan kepercayaan diri dan kemandiriannya.

Dalam implementasi berolahraga renang, anak-anak autis tidak dapat melakukan aktifitas tersebut secara sendiri dan sangat memerlukan pengawasan. Pengawas dalam hal ini berfungsi untuk menjaga dari ketidakmampuannya menyeimbangkan berfikir dan bertingkah laku. Pelatih renang dianggap yang paling mampu dalam mengawasi anak autisme dalam berenang. Pelatih renang memberikan metode pelatihan harus dapat membedakan cara melatih dengan anak-anak yang normal.

Jadi yang menjadi latar belakang penelitian ini adalah menjelaskan implementasi pelatihan olahraga renang anak autisme, dan sekaligus memberikan gambaran bahwa dengan mengikuti pelatihan olahraga renang untuk anak autisme akan mengalami perubahan dan peningkatan motoriknya.

\section{Latihan}

Setiap orang harus meningkatkan kualitas dirinya, dalam hal ini adalah kualitas fisik yang harus dikembangkan. Kualitas fisik seseorang dapat berkembang jika diiringi aktivitas. Aktivitas yang dimaksud adalah aktivitas yang menunjang terhadap 
perkembangan fisik seseorang. Latihan adalah aktivitas manusia yang menunjang terhadap pemenuhan kebutuhan fisiknya. Berikut adalah beberapa pengertian latihan yang diungkapkan oleh ahli: Harsono (1988:101) bahwa "latihan adalah proses yang sistematis dari berlatih atau bekerja yang dilakukan secara berulang ulang, dengan kian hari kian menambah jumlah beban latihan atau pekerjaaannya."

Jadi bisa kita simpulkan bahwa tujuan akhir latihan dalam bidang olahraga adalah untuk meningkatkan penampilan olahraga dalam melakukan aktivitas atau latihan harus sistematis. Sistematis yang dimaksud adalah setiap aktivitas harus disesuaikan dengan kemampuan masing masing orang dari yang mudah ke yang sukar, dari yang sederhana ke yang rumit. Selain itu, harus tetap diingat bahwa ketika melaksanakan latihan kemampuan fisik, seseorang harus memperhatikan pengulangan dari setiap aktivitas yang dilakukan. Hal tersebut dilakukan untuk mencegah hal-hal yang tidak diinginkan seperti cedera otot, patah tulang, luka, dan sebagainya.

Seseorang yang melakukan suatu aktivitas secara teratur, terencana, berulang-ulang dengan kian hari semakin berat beban kerjanya sering dinyatakan bahwa orang tersebut sedang melakukan latihan. Hal ini didasarkan pada pengertian training yang dijelaskan oleh Harsono (1988:101) bahwa "Training adalah proses yang sistematis dari berlatih atau bekerja, yang dilakukan secara berulang-ulang dengan kian hari kian menambah jumlah beban latihan/pekerjaannya Latihan adalah upaya sadar yang dilakukan secara berkelanjutan dan sistematis untuk meningkatkan kemampuan fungsional raga yang sesuai dengan tuntutan penampilan cabang olahraga itu, untuk dapat menampilkan mutu tinggi cabang olahraga itu baik pada aspek kemampuan dasar (latihan fisik) maupun pada aspek kemampuan keterampilannya (latihan teknik). 
Berdasarkan penjelasan di atas maka dapat disimpulkan bahwa latihan adalah suatu proses pemberdayaan diri melalui suatu aktivitas yang sistematis, berulang-ulang, dan kian hari kian menambah beban tugasnya.

\section{Olahraga Renang}

Renang adalah olahraga yang melombakan kecepatan atlet renang dalam berenang. Gaya renang yang diperlombakan adalah gaya bebas, gaya kupu-kupu, gaya punggung, dan gaya dada. Perenang yang memenangkan lomba renang adalah perenang yang menyelesaikan jarak lintasan tercepat. Pemenang babak penyisihan maju ke babak semifinal, dan pemenang semifinal maju ke babak final.

Bersama-sama dengan loncat indah, renang indah, renang perairan terbuka, dan polo air, peraturan perlombaan renang ditetapkan oleh badan dunia bernama Federasi Renang Internasional (FINA). Persatuan Renang Seluruh Indonesia (PRSI) adalah induk organisasi cabang olahraga renang di Indonesia.
Renang menjadi salah satu cabang olahraga yang dilombakan sejak Olimpiade Athena 1896. Nomor renang putri dilombakan sejak Olimpiade Stockholm 1912. Pada 1902, Richard Cavill memperkenalkan renang gaya bebas. Federasi Renang Internasional dibentuk pada 1908. Gaya kupu-kupu pertama kali dikembangkan pada tahun 1930-an. Pada awalnya, gaya kupu-kupu merupakan variasi gaya dada sebelum dianggap sebagai gaya renang tersendiri pada 1952.

Renang telah dikenal sejah zaman pra-sejarah. Dari gambar-gambar yang berasal dari zaman batu diketahui adanya gua-gua bagi para perenang di dekat Wadi Sora sebelah barat daya Mesir. Di Jepang, renang adalah kemampuan yang harus dimiliki oleh para samurai. Sejarah mencatat, pertandingan renang pertama diselenggarakan oleh Kaisar Suigui pada 36 sebelum Masehi.

Pertandingan renang yang memperebutkan gelar juara telah dimulai di Eropa sekitar tahun 1800 dan sebagian besar menggunakan gaya dada. Renang gaya bebas pertama kali 
dikenalkan oleh Arthur Trudgen. Gaya ini kemudian mulai dikombinasikan dengan gaya kaki yang menendang oleh Richard Cavill pada 1902. Di abad pertengahan, renang termasuk dalam tujuh kemahiran yang harus dimiliki oleh para ksatria termasuk berenang dengan membawa senjata.

Olahraga renang pertama kali dipertandingkan dalam Olimpiade modern 1896 di Athena, Yunani. Pada Olimpiade ini, hanya empat nomor yang dipertandingkan dari rencana semula enam nomor. Masingmasing adalah nomor 100 meter, 500 meter, 1.200 meter, nomor bebas, dan 100 meter bagi para pelaut. Olimpiade kedua diselenggarakan di Paris, Prancis pada 1900 dan mempertandingkan nomor 200 m, 1.000 $\mathrm{m}, 4.000 \mathrm{~m}$, nomor bebas, $200 \mathrm{~m}$ gaya dada, dan $200 \mathrm{~m}$ nomor beregu. Seiring dengan perkembangan olah raga renang renang semakin popular. Penggemar renang semakin bertambah. Bahkan, seringkali anak-anak diajarkan renang pada usia sangat dini. a. Macam - Macam Gaya Dalam Olahraga Renang

- Renang Gaya Bebas, gaya bebas (bahasa Inggris: front crawl) adalah berenang dengan posisi dada menghadap ke permukaan air. Kedua belah lengan secara bergantian digerakkan jauh ke depan dengan gerakan mengayuh, sementara kedua belah kaki secara bergantian dicambukkan naik turun ke atas dan ke bawah. Sewaktu berenang gaya bebas, posisi wajah menghadap ke permukaan air. Pernapasan dilakukan saat lengan digerakkan ke luar dari air, saat tubuh menjadi miring dan kepala berpaling ke samping. Sewaktu mengambil napas, perenang bisa memilih untuk menoleh ke kiri atau ke kanan. Dibandingkan gaya berenang lainnya, gaya bebas merupakan gaya berenang yang bisa membuat tubuh melaju lebih cepat di air. 
- Renang Gaya Dada, gaya dada atau gaya katak adalah berenang dengan posisi dada menghadap ke permukaan air, namun berbeda dari gaya bebas, batang tubuh selalu dalam keadaan tetap. Kedua belah kaki menendang ke arah luar sementara kedua belah tangan diluruskan di depan. Kedua belah tangan dibuka ke samping seperti gerakan membelah air agar badan maju lebih cepat ke depan. Gerakan tubuh meniru gerakan katak sedang berenang sehingga disebut gaya katak. Pernapasan dilakukan ketika mulut berada di permukaan air, setelah satu kali gerakan tangan-kaki atau dua kali gerakan tangan-kaki.

- Renang Gaya Punggung, gaya punggung adalah berenang dengan posisi punggung menghadap ke permukaan air. Gerakan kaki dan tangan serupa dengan gaya bebas, tapi dengan posisi tubuh telentang di permukaan air. Kedua belah tangan secara bergantian digerakkan menuju pinggang seperti gerakan mengayuh. Mulut dan hidung berada di luar air sehingga mudah mengambil atau membuang napas dengan mulut atau hidung.

-Renang Gaya Kupu - Кupu, gaya kupukupu adalah salah satu gaya berenang dengan posisi dada menghadap ke permukaan air. Kedua belah lengan secara bersamaan ditekan ke bawah dan digerakkan ke arah luar sebelum diayunkan ke depan. Sementara kedua belah kaki secara bersamaan menendang ke bawah dan ke atas seperti gerakan sirip ekor ikan atau lumba-lumba. Udara dihembuskan kuatkuat dari mulut dan hidung sebelum kepala muncul dari air, dan udara dihirup lewat mulut ketika kepala berada di luar air.

b. Manfaat Renang Bagi Tubuh

- Meningkatkan Kualitas Jantung dan Peredaran Darah, jantung merupakan organ tubuh yang memompa darah 
agar mengalir ke seluruh tubuh, sedangkan darah tersebut mengangkut sari - sari makanan dan oksigen sehingga terjadi proses pembakaran serta menghasilkan energi yang diperlukan untuk bergerak.

- Meningkatkan Kapasitas Vital Paru Paru, paru - paru berfungsi untuk mengambil oksigen yang sangat diperlukan dalam proses oksidasi (pembakaran). Renang akan melatih kerjapau - paru dan meningkatkan kemampuan paru - paru untuk mengambil oksigen yang banyak. Dengan terpenuhinya oksigen maka proses pembakaran dalam tubuh menjadi lancar sehingga energi yang diperlukan dapat terpenuhi.

- Mempengaruhi Otot Mejadi Berisi, ketika berenang akan terjadi gerakan otot yang dinamis dan oto akan bekerja terus menerus. Hal ini kan membuat serabut otot bertambah banyak dan bertambah kuat. Sehingga otot - otot tubuh akan kelihatan lebih berisi/padat.

\section{Anak Autisme}

Autisme adalah kelainan perkembangan sistem saraf pada seseorang yang dialami sejak lahir ataupun saat masa balita. Karakteristik yang menonjol pada seseorang yang mengidap kelainan ini adalah kesulitan membina hubungan sosial, berkomunikasi secara normal maupun memahami emosi serta perasaan orang lain. Autisme merupakan salah satu gangguan perkembangan yang merupakan bagian dari Kelainan Spektrum Autisme atau Autism Spectrum Disorders (ASD) dan juga merupakan salah satu dari lima jenis gangguan dibawah payung Gangguan Perkembangan Pervasif atau Pervasive Development Disorder (PDD). Autisme bukanlah penyakit kejiwaan karena Autisme merupakan suatu gangguan yang terjadi pada otak sehingga menyebabkan otak tersebut tidak dapat berfungsi selayaknya otak normal 
dan hal ini termanifestasi pada perilaku penyandang autisme.

Gejala-gejala autisme dapat muncul pada anak mulai dari usia tiga puluh bulan sejak kelahiran hingga usia maksimal tiga tahun. Penderita autisme juga dapat mengalami masalah dalam belajar, komunikasi, dan bahasa. Seseorang dikatakan menderita autisme apabila mengalami satu atau lebih dari karakteristik berikut: kesulitan dalam berinteraksi sosial secara kualitatif, kesulitan dalam berkomunikasi secara kualitatif, menunjukkan perilaku yang repetitif, dan mengalami perkembangan yang terlambat atau tidak normal.

Di Amerika Serikat, kelainan autisme empat kali lebih sering ditemukan pada anak lelaki dibandingkan anak perempuan dan lebih sering banyak diderita anak-anak keturunan Eropa Amerika dibandingkan yang lainnya. Di Indonesia, pada tahun 2013 diperkirakan terdapat lebih dari 112.000 anak yang menderita autisme dalam usia 5-19 tahun. Sedangkan prevalensi penyandang autisme di seluruh dunia menurut data UNESCO pada tahun 2011 adalah 6 di antara 1000 orang mengidap autisme.

Secara historis, para ahli dan peneliti dalam bidang autisme mengalami kesulitan dalam menentukan seseorang sebagai penyandang autisme atau tidak. Pada awalnya, diagnosa disandarkan pada ada atau tidaknya gejala namun saat ini para ahli setuju bahwa autisme lebih merupakan sebuah kontinuum. Gejala-gejala autisme dapat dilihat apabila seorang anak memiliki kelemahan di tiga domain tertentu, yaitu sosial, komunikasi, dan tingkah laku yang berulang. Aarons dan Gittents (Online) merekomendasikan adanya suatu pendekatan deskriptif dalam mendiagnosa autisme sehingga menyertakan pengamatanpengamatan yang menyeluruh di settingsetting sosial anak sendiri. Settingya mungkin di sekolah, di taman-taman bermain atau mungkin di rumah sebagai lingkungan seharihari anak dimana hambatan maupun kesulitan 
mereka tampak jelas di antara teman-teman sebaya mereka yang normal.

Anak dengan autisme dapat tampak normal pada tahun pertama maupun tahun kedua dalam kehidupannya. Para orang tua seringkali menyadari adanya keterlambatan kemampuan berbahasa dan cara-cara tertentu yang berbeda ketika bermain serta berinteraksi dengan orang lain. Anak-anak tersebut mungkin dapat menjadi sangat sensitif atau bahkan tidak responsif terhadap rangsangan-rangasangan dari kelima panca inderanya (pendengaran, sentuhan, penciuman, rasa dan penglihatan). Perilakuperilaku repetitif (mengepak-kepakan tangan atau jari, menggoyang-goyangkan badan dan mengulang-ulang kata) juga dapat ditemukan. Perilaku dapat menjadi agresif (baik kepada diri sendiri maupun orang lain) atau malah sangat pasif. Besar kemungkinan, perilakuperilaku terdahulu yang dianggap normal mungkin menjadi gejala-gejala tambahan. Selain bermain yang berulang-ulang, minat yang terbatas dan hambatan bersosialisasi, beberapa hal lain yang juga selalu melekat pada para penyandang autisme adalah responrespon yang tidak wajar terhadap informasi sensoris yang mereka terima, misalnya; suarasuara bising, cahaya, permukaan atau tekstur dari suatu bahan tertentu dan pilihan rasa tertentu pada makanan yang menjadi kesukaan mereka.

Beberapa atau keseluruhan karakteristik yang disebutkan berikut ini dapat diamati pada para penyandang autisme beserta spektrumnya baik dengan kondisi yang teringan hingga terberat sekalipun.

- Hambatan dalam komunikasi, misal: berbicara dan memahami bahasa.

- Kesulitan dalam berhubungan dengan orang lain atau obyek di sekitarnya serta menghubungkan peristiwaperistiwa yang terjadi.

- Bermain dengan mainan atau bendabenda lain secara tidak wajar.

- Sulit menerima perubahan pada rutinitas dan lingkungan yang dikenali. 
- Gerakkan tubuh yang berulang-ulang atau adanya pola-pola perilaku yang tertentu

Para penyandang Autisme beserta spektrumnya sangat beragam baik dalam kemampuan yang dimiliki, tingkat intelegensi, dan bahkan perilakunya. Beberapa di antaranya ada yang tidak 'berbicara' sedangkan beberapa lainnya mungkin terbatas bahasanya sehingga sering ditemukan mengulang-ulang kata atau kalimat (echolalia). Mereka yang memiliki kemampuan bahasa yang tinggi umumnya menggunakan tema-tema yang terbatas dan sulit memahami konsep-konsep yang abstrak. Dengan demikian, selalu terdapat individualitas yang unik dari individuindividu penyandangnya.

Terlepas dari berbagai karakteristik di atas, terdapat arahan dan pedoman bagi para orang tua dan para praktisi untuk lebih waspasa dan peduli terhadap gejala-gejala yang terlihat. The National Institute of Child Health and Human Development (NICHD) di Amerika
Serikat menyebutkan 5 jenis perilaku yang harus diwaspadai dan perlunya evaluasi lebih lanjut:

- Anak tidak bergumam hingga usia 12 bulan

- Anak tidak memperlihatkan kemampuan gestural (menunjuk, dada, menggenggam) hingga usia 12 bulan

- Anak tidak mengucapkan sepatah kata pun hingga usia 16 bulan

- Anak tidak mampu menggunakan dua kalimat secara spontan di usia 24 bulan

- Anak kehilangan kemampuan berbahasa dan interaksi sosial pada usia tertentu

Adanya kelima 'lampu merah' di atas tidak berarti bahwa anak tersebut menyandang autisme tetapi karena karakteristik gangguan autisme yang sangat beragam maka seorang anak harus mendapatkan evaluasi secara multidisipliner yang dapat meliputi; Neurolog, Psikolog, Pediatric, Terapi Wicara, 
Paedagogi dan profesi lainnya yang memahami persoalan autisme.

Intensitas dari treatment perilaku pada anak dengan autisme merupakan hal penting, namun persoalan-persoalan mendasar yang ditemui di Indonesia menjadi sangat krusial untuk diatasi lebih dahulu. Tanpa mengabaikan faktor-faktor lain, beberapa fakta yang dianggap relevan dengan persoalan penanganan masalah autisme di Indonesia di antaranya adalah:

- Kurangnya tenaga terapis yang terlatih di Indonesia. Orang tua selalu menjadi pelopor dalam proses intervensi sehingga pada awalnya pusat-pusat intervensi bagi anak dengan autisme dibangun berdasarkan kepentingan keluarga untuk menjamin kelangsungan pendidikan anak mereka sendiri.

- Belum adanya petunjuk treatment yang formal di Indonesia. Tidak cukup dengan hanya mengimplementasikan petunjuk teatment dari luar yang penerapannya tidak selalu sesuai dengan kultur kehidupan anak-anak Indonesia.

- Masih banyak kasus-kasus autisme yang tidak di deteksi secara dini sehingga ketika anak menjadi semakin besar maka semakin kompleks pula persoalan intervensi yang dihadapi orang tua. Para ahli yang mampu mendiagnosa autisme, informasi mengenai gangguan dan karakteristik autisme serta lembaga-lembaga formal yang memberikan layanan pendidikan bagi anak dengan autisme belum tersebar secara merata di seluruh wilayah di Indonesia.

- Belum terpadunya penyelenggaraan pendidikan bagi anak dengan autisme di sekolah. Dalam Pasal 4 UU No. 20/2003 tentang Sistem Pendidikan Nasional telah diamanatkan pendidikan yang demokratis dan tidak diskriminatif dengan menjunjung tinggi hak asasi manusia, dukungan ini 
membuka peluang yang besar bagi para penyandang autisme untuk masuk dalam sekolah-sekolah umum (inklusi) karena hampir 500 sekolah negeri telah diarahkan oleh pemerintah untuk menyelenggarakan inklusi.

- Permasalahan akhir yang tidak kalah pentingnya adalah minimnya pengetahuan baik secara klinis maupun praktis yang didukung dengan validitas data secara empirik (Empirically

Validated

Treatments/EVT) dari penangananpenanganan masalah autisme di Indonesia. Studi dan penelitian autisme selain membutuhkan dana yang besar juga harus didukung oleh validitas data empirik, namun secara etis tentunya tidak ada orang tua yang menginginkan anak mereka menjadi percobaan dari suatu metodologi tertentu. Kepastian dan jaminan bagi proses pendidikan anak merupakan pertimbangan utama bagi orang tua dalam memilih salah satu jenis treatment bagi anak mereka sehingga bila keraguan ini dapat dijawab melalui otoritas-otoritas ilmiah maka semakin terbuka informasi bagi masyarakat luas mengenai pengetahuan-pengetahuan baik yang bersifat klinis maupun praktis dalam proses penanganan masalah autisme di Indonesia.

\section{Tujuan}

Adapun tujuan penelitian dalam tulisan ini adalah mengetahui pelaksanaan latihan olahraga renang anak autisme yang sedang latihan pada kolam renang Cemara Asri Medan.

\section{METODE}

Penelitian ini menggunakan metode penelitian deskriptif dengan pendekatan kualitatif. Dalam hal ini peneliti menggunakan teknik pengumpulan data: wawancara, observasi dan dokumentasi rekaman percakapan pada saat penelitian. Teknik analisa data dalam 
penelitian ini dengan triangulasi menggabungkan data-data dari naskah wawancara, catatan lapangan, foto, vidio tape recorder dan catatan kecil (memo). Lokasi penelitian ini adalah di kolam renang Cemara Medan di jalan Cemara Komp. Cemara Asri Medan. Adapun waktu penelitian dilaksanakan pada Desember 2015 s/d Januari 2016. Subyek dalam penelitian ini adalah 5 orang yang terdiri dari pelatih renang khusus, anak autis dan orang tua anak autis.

\section{HASIL DAN PEMBAHASAN}

Di dalam penelitian ini memperoleh hasil penelitian dari masing-masing sampel yaitu: Pelatih, Anak autisme dan Orang tua dari anak autisme. Pembahasan dalam penelitian ini pada 4 dimensi penting guna menggambarkan Implementasi latihan olahraga renang anak autisme adalah: a) Rencana proses latihan, b) Penyusunan progam latihan, c) Pelaksanaan latihan, d) Evaluasi Latihan. Berdasarkan hasil penelitian menunjukkan bahwa:

\section{a) Rencana Proses Latihan}

Berdasarkan hasil penelitian dapat di analisis dan disimpulkan bahwa pelaksanaan persiapan pelatih sebelum latihan dimulai sudah maksimal. Walaupun pelatih selalu mempersiapkan program yang akan di ajarkannya kepada anak autisme selama latihan berlangsung, pelatih memberikan latihan fisik dan mental terlebih dahulu kepada anak autisme.

Dari hasil wawancara dengan orang tua, dapat disimpulkan, masih banyak orang tua dari anak autisme belum paham manfaat dari olahraga renang terhadap perkembangan motorik anak autisme. Pada umumnya orang tua mengetahui informasi tentang keberadaan pelatihan olahraga renang anak autisme dari rekan-rekan yang sudah anaknya mendapatkan pelatihan di kolam renang Cemara Asri Medan. Awalnya banyak orang tua dari anak autisme tidak percaya, setelah melihat langsung hasilnya dan berkonsultasi dengan pelatih para orang tua baru yakin untuk anaknya di titipkan untuk diberikan latihan renang. 
Sampai saat ini orang tua dari anak autisme yakin dan percaya manfaat dan pengaruh dari latihan olahraga renang terhadap perkembangan motorik anak-anak mereka. Proses latihan yang diterapkan juga sangat baik dan telah dipersiapkan sebelum latihan berlangsung. Orang tua dari anak autisme sangat mengharapkan kegiatan ini terus berlangsung dan untuk kedepannnya dapat dikembangkan lagi program-program atau model-model lain untuk alternatif penanganan anak-anak autisme di Kota Medan.

\section{b) Penyusunan Progam Latihan}

Dari hasil wawancara tidak diperoleh adanya kendala dari pelatih memberikan program terhadap anak autisme. Pelaksanaan latihan renang anak autisme sama halnya seperti latihan renang anak normal lainnya, hanya saja perbedaan pada sikap pelatih yang harus lebih peka melihat kondisi anak autisme pada saat program diberikan. Karena anak autisme umumnya tidak bisa di atur, kalau moodnya lagi tidak baik. Sebelum mulai latihan pelatih biasanya terlebih dahulu melihat mimik muka atau tingkah laku anak autisme apakah siap untuk latihan atau tidak. Jika tidak siap maka perintah apapun dari pelatih akan di abaikan dan anak autisme akan lebih senang bermainmain.

Dari analis yang dilakukan latihan olahraga renang anak autisme di kolam renang Cemara Asri Medan menggunakan model pendekatan terlebih dahulu, setelah anak autisme merasa nyaman dan senang, maka di ajak masuk kekolam dan diberikan program latihan renang. Cara ini berdampak lebih baik terhadap anak autisme, program yang ada saat ini adalah selain program latihan renang, anak autisme diberikan program interaksi sosial, komunikasi yang baik, pengendalian emosi dan kontak mata atau kode. Terlihat dari hasil wawancara, dokumentasi, pelatih mempersiapkan program latihan dalam tiap minggunya. Pelatih tidak pernah memberikan program menurut tingkat keautissan anak, karena yang menjadi target latihan ini adalah anak autisme tidak takut dengan air, bisa mengambang di air dan berenang dengan baik 
saja. Tidak dituntut hasil tercepat. Sampai saat ini orang tua dari anak autisme sangat senang apabila anak-anak mereka tidak takut air dan apalagi bisa berenang dengan baik.

Program latihan olahraga renang anak autisme di kolam renang Cemara Asri Medan sampai saat ini berjalan dengan baik. Terlihat dari hasil wawancara dengan orang tua dari anak autisme, orang tua dari anak autisme tidak pernah mempermasalahkan program yang dilaksanakan pelatih. Terjadinya peningkatan motorik dan perubahan yang signifikan terhadap anak-anak autisme saja orang tua sudah sangat senang.

\section{c) Pelaksanaan Latihan}

Pelaksanaan dan waktu latihan renang anak autisme di kolam renang Cemara Asri Medan dilakukan 4x seminggu dari jam 15.30-16.30 Wib. Dari hasil wawancara dengan pelatih dan orang tua dapat disimpulkan pelaksanaan latihan sudah berjalan dengan baik, hanya saja karena terlalu ramainya pengunjung kolam sehingga proses latihan tidak optimal. Perhatian anak autisme pada saat latihan terkadang kurang fokus. Memang disadari kolam renang yang digunakan bukanlah kolam khusus anak autisme.

\section{d) Evaluasi Latihan}

Berdasarkan hasil penelitian terlihat jelas hasil dan peningkatan yang luar biasa dari proses latihan anak autisme, hasil ini adalah wawancara langsung terhadap orang tua dari anak autisme, pelatih dan anak autisme. Implementasi hasil latihan olahraga renang anak autisme berjalan dengan baik sesuai dengan yang diharapkan orang tua dari anak autisme dan pelatih. Walaupun program latihan anak autisme belum memiliki standar khusus dari lembaga yang berhak menangani anak-anak autisme. Tetapi implementasi latihan olahraga renang yang diterapkan terhadap anak autisme di kolam renang Cemara Asri Medan memiliki kualitas yang baik dan teruji.

\section{SIMPULAN}

Berdasarkan hasil penelitian dan pembahasan dapat disimpulkan bahwa implementasi latihan olahraga renang yang diterapkan 
terhadap anak autisme di kolam renang Cemara Asri Medan dapat dikatakan baik. Hal tersebut keterlihatan dari implementasi:

a) Rencana proses latihan yang dilakukan sudah berjalan dengan baik

b) Penyusunan progam latihan yang dilaksanakan sudah berjalan dengan baik

c) Pelaksanaan latihan yang dilaksanakan sudah berjalan dengan baik

d) Evaluasi Latihan yang dilaksanakan dudah berjalan dengan baik.

\section{SARAN}

Dari pembahasan dan kesimpulan diharapkan kedepannya perlunya pemikirakan yang lebih baik lagi dalam menangani anak-anak autisme:

1. Kepada pemerintah pusat dan daerah agar mengkaji lebih dalam lagi amanat UndangUndang Dasar tentang hak dan kewajiban seluruh masyarakat Indonesia tanpa perbedaan apapun.

2. Pemerintah wajib menyediakan tempattempat penanganan anak-anak autisme yang layak guna dan dikelola dengan baik.
3. Perlunya pemassalan dan sosialisasi dari pemerintah dalam penanganan anak autisme, karena anak autisme juga berhak mendapatkan perlakuan yang layak.

4. Perlu adanya dalam hal peningkatan SDM pelatih anak autisme yang profesional dan berdampak pada peluang kerja baru yang cukup menjanjikan.

\section{DAFTAR PUSTAKA}

Harsono. (1988). Coaching dan Aspek Psikologi dalam Coahing. Jakarta: Dirjen Dikti.

Medan Punya Com.(2010). Jumlah Anak Autis di Indonesia Meningkat (Online), (http://www.medanpunya.com/medan/6 748-jumlah-anak-autis-di-indonesiameningkat), di akases 16 Oktober 2013.

M. Murni. (2006). Teori dan praktek Melatih Khusus. Jakarta: Balai Pustaka.

Republika. (2009). 112.000 Anak Indonesia Diperkirakan Menyandang Autisme. (Online),(http://www.republika.co.id/be rita/nasional/umum/13/04/09/mkz2un112000-anak-indonesia-diperkirakanmenyandang-autisme), di akases 10 April 2014

Trigonal. (2013). Pengertian latihan menurut ahli. (Online), (http ://www.trigonalworld.com/2013/04/pen gertian-latihan-menurut-ahli.html), di akses pada tanggal 6 November 2013. 
Weblog. (2014). Artikel Olahraga Renang. (Online), ( http : // ekowarlianto . weblog .esaunggul.ac.id/2013/04/03/artikelolahraga-renang/) diakses 6 April 2014.

Wikipedia. (2014). Renang. (Online), ( http : // id . wikipedia.org / wiki / Renang _ \% 28 olahraga \%29), diakses 2 Maret 2014.

Wikipedia.(2013). Autisme. (Online), (http://id.wikipedia.org/wiki/Autisme), diakses 11 November 2013. 